\title{
DILSTORE software for ecological status assessment of lakes based on benthic diatoms
}

\author{
Éva HajnaL ${ }^{1 *}$, Csilla Stenger-KovÁcS ${ }^{1}$, Éva Ács ${ }^{2} \&$ Judit PADISÁK ${ }^{1}$ \\ ${ }^{1}$ University of Pannonia, Department of Limnology, H-8201, Veszprém, Pf. 158. Hungary; *corresponding author: \\ hajnal@limnologia.hu \\ ${ }^{2}$ Institute of Ecology and Botany of HAS, Hungarian Danube Research Station, H-2131, Göd, Jávorka S. u.14. \\ Hungary
}

\begin{abstract}
Until recently, only few diatom indices were developed for monitoring littoral zones of lakes. The available indices are not applicable for all lake types because species lists and environmental constraints' ranges are different. So far, four diatom indices (SCIL, TDIL, S, TI) were developed that use attached diatoms for ecological status assessment therefore a need arose to ease index calculation similarly as it is a wide spread practice in status assessment of rivers by means of the well known OMNIDIA software. DILSTORE 1.1 software has three main functions; (i) calculation of diatom indices and community attributes; (ii) storage and listing of primary diatom data series and (iii) it contains a taxon name coder and a spelling-check program. It can be used as a peripheral aid to generate data sheets for the OMNIDIA. The DILSTORE 1.1 software was developed for IBM PC compatible computers, for Windows users. According to the experiences, the DILSTORE 1.1 software can make the regular lake monitoring practice considerably faster.
\end{abstract}

Key words: benthic diatoms, diatom indices, data storage, index calculation, code converter, spelling check, monitoring

\section{Introduction}

After issuing the Water Framework Directive (WFD; European Parliament and Council, 2000), an intensive research has started that aimed to search for appropriate biotic indicators and to delimit their inherent, geographical or methodological limitations. Of aquatic biota, those gained special interests that were listed as target Biological Quality Elements (BQE). One of the applied indicators is the phytobenthos, often dominated by diatoms. Diatoms have a number of superior indicator properties in comparison with other BQEs. They form a large part of biodiversity in lentic and lotic environments, their sampling is relatively easy, their persistent frustules in combination with the commonly applied mounting technique allow to make permanent slides that are excellent whenever quality assurance is of relevance. Since their generation times are rather short, they respond fast to ecologically relevant changes (e.g. Stoermer \& Smol 1999). On the other hand, being attached organisms and having resistant frustules, they can successfully reflect time-integrated environmental influences.

A number of diatom indices are used to assess species-environment relationships and their calculation are facilitated by the widespread OMNIDIA software (RotT 1991, LeCoINTE et al. 1993, Rотт et al. 1997, 2003). The indices that are included in the OMNIDIA were largely developed using stream diatoms and they are successfully used for water quality status assessment of running waters.

In lakes, phytoplankton and macrophytes were more frequently used BQEs than attached diatoms despite it was shown in several studies (e.g PoulíčKová et al. 2004, Schaumburg et al. 2004, Kelly et al. 2008) that transfer functions generated for diatoms are powerful in ecological status assessment of lakes. Nevertheless, some diatom-based indices were developed for lakes in the recent past.

HoFMANN's (1994) TI index was developed to assess trophic status for German lakes and was proved to provide similarly reliable results 
as the macrophyte indices (Schaumburg et al. 2004). The TDIL (Stenger-Kovács et al. 2007) was based on a TP model and was developed for the Hungarian lake types, which are lowland, shallow, permanent or periodic with calcareous or calcareous + slightly saline hydrogeochemistry, with conductivities $<3000 \mu \mathrm{S} \mathrm{cm}^{-1}$ The $\mathrm{S}$ index (SGRo et al. 2007), used for the American lakes, is also a TP based one (REAVIE et al. 2006) and its development was based on the nearshore wetlands of the Laurentian Great Lakes. The SCIL index (Sodic Conductivity Index For Lakes; Ács et al. 2007) is considerably different, since it used a conductivity inference model and data from two slightly saline lakes, Lake Velencei and Lake Fertő (Neusiedlersee) in the Carpathian Basin. These two lakes represent unique types in the Hungarian lake typology (PADISÁK et al. 2006). Some basic features of the above four indices are summarized in Table 1.

In this paper, we provide a short description of the DILSTORE 1.1 software that was developed to facilitate calculation of the above four indices, which could not be computed with OMNIDIA software and the basic data for calculations are documented.

\section{DILSTORE 1.1 software principles and} description

DILSTORE 1.1 software's main purpose is to calculate diatom indices from spreadsheets and to store results. Experiences of using the OMNIDIA software (LECOINTE et al. 1993) and development

Table 1. Some important features of the lake diatom indices (species number: the really used species for calculations; range: the range of the indicator and sensitivity values; values: the computed index range). EC = Environmental constraints, Cond. $=$ Conductivity.

\begin{tabular}{lcccc}
\hline $\begin{array}{l}\text { Index } \\
\text { name }\end{array}$ & $\begin{array}{c}\text { Species } \\
\text { number }\end{array}$ & EC & Range & Value \\
\hline TDIL & 127 & TP & $0.01-5.72 \mathrm{mg} \mathrm{l}^{-1}$ & $1-5$ \\
SCIL & 138 & Cond. & $<3500 \mu \mathrm{S} \mathrm{cm}^{-1}$ & $1-20$ \\
TI & 304 & TP & $0.006-0.181 \mathrm{mg} \mathrm{l}^{-1}$ & $1-5$ \\
S & 402 & TP & $0.001-0.521 \mathrm{mg} \mathrm{l}^{-1}$ & $1-10$ \\
\hline
\end{tabular}

of the ALMOBAL (Hajnal \& PAdisák 2008) and ALMOL (PADISÁK et al. 2009) phytoplankton databases helped us in organizing this program and its database. The calculation of indices of DILSTORE software is based on the equation by ZELINKA \& MARVAN (1961):

$$
I=\frac{\sum a_{k} s_{k} v_{k}}{\sum a_{k} s_{k}}
$$

where $I$ is the value of the index, $a_{k}$ is the relative abundance of $\mathrm{k}^{\text {th }}$ species, the $s_{k}$ is the sensitivity and $v_{k}$ is the indicator value of the $\mathrm{k}^{\text {th }}$ species. The $s$ and $v$ values are categories, which were evaluated on the basis of the optimum and tolerance ranges of diatom species. These ranges were estimated with weighted average method (WA).

DILSTORE 1.1 software is applicable for calculating diatom indices for lakes and includes the following indices: TDIL (STENGER-KovÁcs et al. 2007), SCIL (Ács 2007), TI (Hofmann 1994) and S (SGRo et al. 2007).

The DILSTORE software was developed for IBM PC compatible computers, for Windows users. The software was implemented in DELPHI 5.0 Professional Edition environment. It can be connected to Paradox type databases. The demo version can be downloaded from www.limnologia. hu/perifiton/dilstore website.

DILSTORE 1.1 software has three main functions; (i) calculation of diatom indices and community attributes; (ii) storage and listing of primary diatom data series and (iii) taxon name coder and spelling-check program. Installing and using DILSTORE 1.1 does not exceed the level of average computer users. It is running with Windows 98, 2000 or XP and at least MS Excel 1997.

\section{Calculation of ecological state indices}

Data input of DILSTORE 1.1 can be achieved from spreadsheets. Standard file format is .csv, which can be produced with MS Excel or StarOffice easily. It is also applicable as an input file for online databases. This file contains sample codes and date; taxon names and codes and abundance values of each diatom species (Fig. 1a).

After loading the spreadsheets, the software calculates the previously described diatom indices. It also calculates general community attributes, as species number, Shannon diversity, evenness, and displays them into the bottom of the sheet. 

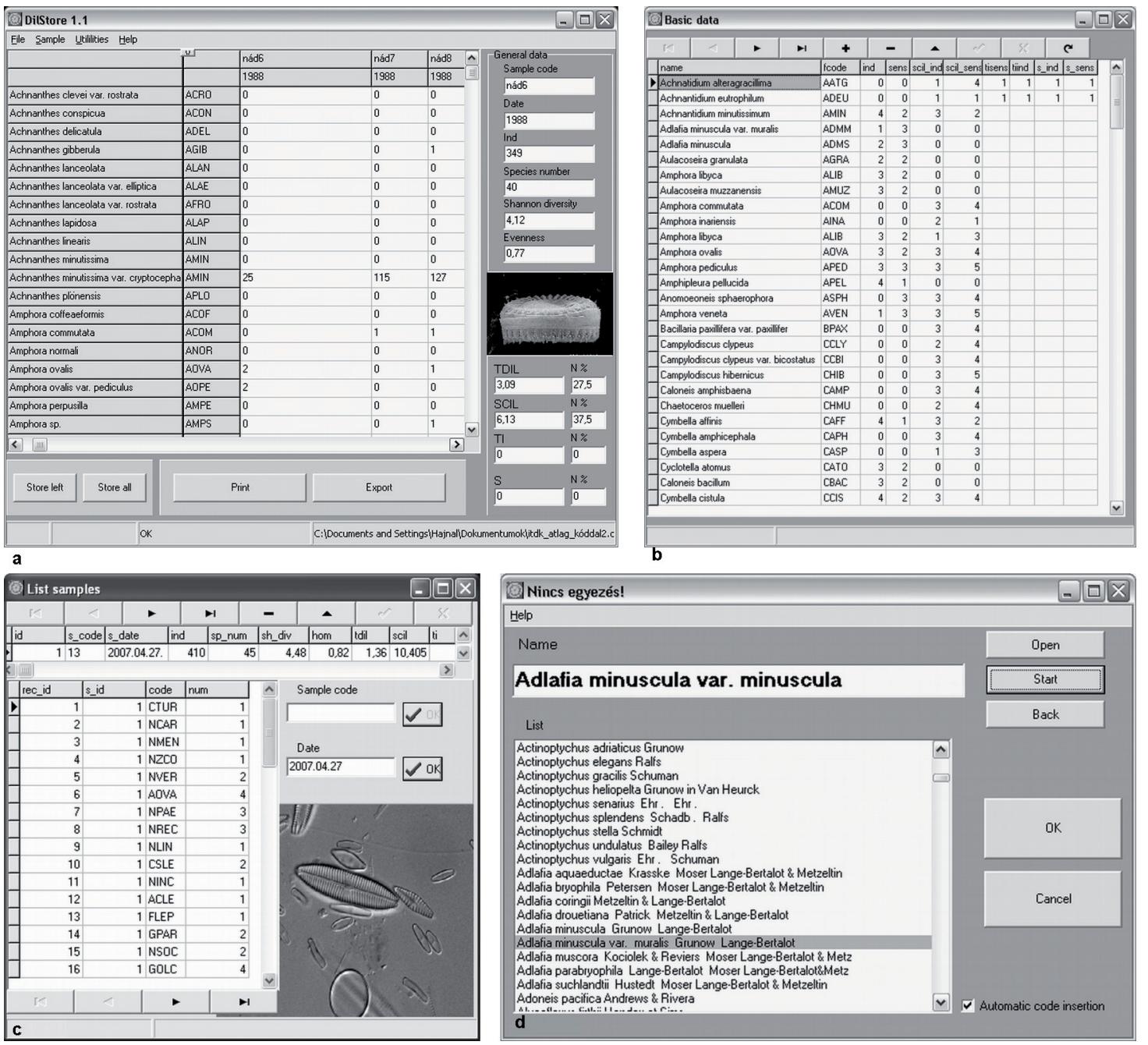

Fig. 1. The main functions of DILSTORE 1.1: (a) primary diatom data series and results; (b) querying and modifying basic data; (c) listing of diatom datasets by date and sample code; (d) taxon code searching form.

For estimating the usefulness of the calculated indices, the number of effectively used species and the percentage of the used species number to the total species number of the sample is also computed.

\section{Data storage management}

DILSTORE 1.1 software has an own paradox type database for data storage. It contains three tables. One of the tables stores the basic data for computing, moreover taxon names, taxon codes, indicator and sensitivity values of each species. The taxon codes have, similarly to the OMNIDIA software, four character codes and they are identical with the OMNIDIA codes. Those taxa that have no OMNIDIA code got special code, the first character is a number followed by three alphabetical characters. The indicator and sensitivity values can be modified later, or new indices, if based on the ZeLINKA \& MARVAN (1961) equation, can be introduced (Fig. 1b).

The computed results are stored in the database in two other tables, and they can be listed, and presented or printed in sheets. The lists are organized in the order of date or sample code (Fig 1c.).

\section{Management of taxon codes}

DILSTORE software contains a utility, which is searching for the code of algal species half automatically from the database. If the taxon name in the sheet matches exactly to the taxon name in the database, the software inserts the algal code from the database into the sheet. If there is no correct matching, the most similar taxon name is chosen from the database, but the code is inserted into the spreadsheet only after the user's acceptance. The suggested similar taxon names are listed from the database. This utility makes the software usage easy (Fig. 1d). It also helps us 
to use the internationally wide-spread OMNIDIA software conveniently, since the data preparation work is quite quick. On the other hand, this utility is applicable as spelling check program for diatom species names.

\section{Acknowledgement}

This paper is dedicated to Petr Marvan. His contributions and dedication to enhancement of biological monitoring have had a profound influence on development of this branch of science. The development of the DILSTORE 1.1 software was supported by the National Hungarian Science Foundation (OTKA Nr. K 75552).

\section{References}

Ács, É. (2007): A Velencei-tó bevonatlakó algáinak térés időbeli változása, kapcsolata a tó ökológiai állapotával. (Spatial and temporal change of epiphytic algae and their connection with the ecological condition of shallow lake Velenceitó). - Acta Biologica Debrecina, Oecologia Hungariae 17: 9-111.

EC Parliament and Council (2000): Directive of the European Parliament and of the Council 2000/60/EC establishing a framework for community action in the field of water policy. - European Commission PE-CONS 3639/1/100 Rev 1, Luxembourg.

Hajnal, É. \& PAdisÁK, J. (2008): Analysis of longterm ecological status of Lake Balaton based on the ALMOBAL phytoplankton database. Hydrobiologia 599: 227-237.

Hofmann, G. (1994): Aufwuchs-Diatomeen in Seen und ihre Eignung als Indikatoren der Trophie. Bibliotheca Diatomologica 30: 1-241.

Kelly, M.G., King, L., Jones, R.I., Barker, P.A. \& JAMIESON, B.J. (2008): Validation of diatoms as proxies for phytobenthos when assessing ecological status in lakes. - Hydrobiologia 610: 125-129.

Lecointe, C., Coste, M. \& Prygiel, J. (1993): "OMNIDIA" software for taxonomy, calculation of diatom indices and inventories management. - Hydrobiologia 269/270 : 509-513.

PAdisÁk, J., Borics, G., Grigorszky, I. \& SoróczkiPINTÉR, É. (2006): Use of phytoplankton assemblages for monitoring ecological status of lakes within the Water Framework Directive: the assemblage index. - Hydrobiologia 553: $1-14$.

PadisÁk, J., Hajnal, É., Koschel, R. \& Krienitz, L. (2009): The importance of winter phytoplankton composition in contrasting lakes: a deep stratifying and a shallow polymictic. Verhandlungen der internationale Vereinigung für theoretische und angewandte Limnologie
30: 757-760.

PoulíčKovÁ, A., Duchoslav, M. \& Dokulil, M. (2004): Littoral diatom assemblages as bioindicators of lake trophic status: A case study from perialpine lakes in Austria. - Eur. J. Phycol. 39: 143-152.

Reavie, E.D., Axler, R.P., Sgro, G.V., Danz, N.P., Kingston, J.C., Kireta, A.R., Brown, T.N., Hollenhorst, T.P. \& Ferguson, M.J. (2006): Diatom-based weighted-averaging transfer function for Great Lakes coastal water quality: relationship to watershed characteristics. Journal of Great Lakes Research 32: 321-347.

Rotт, E. (1991): Methodological aspects and perspectives in the use of periphyton for monitoring and protecting rivers. - In: WHITTON, B.A., Rott, E. \& Friedrich, G. (eds): Use of algae for monitoring rivers. - pp. 9-16, Insitute für Botanik, Universität Innsbruck, Innsbruck.

Rott, E., Hofmann, G., Pall, K., Pfister, P. \& PIPP, E. (1997): Indikationslisten für Aufwuchsalgen. Teil 1: Saprobielle Indikation. - 73 pp., Bundesministerium für Land- und Forstwirtschaft, Wien.

Rott, E., Pipp, E. \& Pfister, P. (2003): Diatom methods developed for river quality assessment in Austria and a cross-check against numerical trophic indicationmethods used in Europe. Algological Studies 110: 91-115.

Schaumburg, J., Schranz, Ch., Hofmann, G., Stelzer, D., Schneider, S. \& Schmedtue, U. (2004): Macrophytes and phytobenthos as indicators of ecological status in German lakes - a contribution to the implementation of the water framework directive. - Limnetica 32: 302-314.

Sgro, G.V., Reavie, E. D., Kingston, J. C., Kireta, A. R., Ferguson, M.J., Danz, N.P. \& Johansen, J.R. (2007): A diatom quality index from a diatom-based total phosphorus inference model. - Environmental Bioindicators 2:15-34.

Stenger-Kovács, C., Padisák, J., Hajnal, É. \& BuczKó, K. (2007): Epiphytic, littoral diatoms as bioindicators of shallow lake trophic status: Trophic Diatom Index for Lakes (TDIL) developed in Hungary. - Hydrobiologia 589: 141-154.

Stoermer, F. \& Smol, J.P. (1999): The diatoms: Applications for the Environmental and Earth Sciences. - 469 pp., Cambridge University Press, Cambridge.

Zelinka, M. \& Marvan, P. (1961): Zur Präzisirung der biologischen Klassifikation der Reinheit fliessenderGewässer.-Archiv fürHydrobiologie 57: 389-407.

(C) Czech Phycological Society

Received April 25, 2009

Accepted June 2, 2009 